\title{
ANALISIS PERANAN INTERNAL AUDIT DALAM MEWUJUDKAN PELAKSANAAN GOOD CORPORATE GOVERNANCE PADA PT. BANK TABUNGAN NEGARA, TBK MANADO
}

\author{
Ayu Anita Ekaristi Oroh ${ }^{1}$, Lintje Kalangi ${ }^{2}$, Anneke Wangkar $^{3}$ \\ 1,2,3 Jurusan Akuntansi, Fakultas Ekonomi dan Bisnis Universitas Sam Ratulangi, J1. Kampus Bahu, Manado, \\ 95115, Indonesia \\ E-mail : ayuoroh.ao@gmail.com
}

\begin{abstract}
PT. Bank Tabungan Negara, Tbk Manado is one of the branch offices of BUMN's, which must implement Good Corporate Governance in accordance with GCG principles set by the Minister of BUMN PER-01 / MBU /2011. Internal audit is one of the elements in GCG and has a role in overseeing the implementation of corporate management and overseeing any practices undertaken by the company. The implementation of GCG in the bank must follow the rules of BI and follow GCG guidelines by KNKG. Therefore, this study aims to determine the implementation of GCG at the bank and to determine the role of internal audit in realizing the implementation of GCG. This type of research is qualitative descriptive. The method of analysis used in this research is descriptive method with data collection technique such as interview, observation and documentation. The results of this study is Bank Tabungan Negara has implemented GCG according to applicable rules that is by implementing the principles of GCG. Furthermore, internal audit plays a role in realizing the implementation of GCG Bank BTN.
\end{abstract}

Keywords : Analysis, The Role, Internal Audit, Good Corporate Governance, GCG

\section{PENDAHULUAN}

GCG merupakan hal penting dan keharusan bagi setiap perusahaan, baik dalam dunia industry dan bisnis, juga termasuk dunia perbankan. Bank termasuk faktor yang mendukung perkenomian di Indonesia, yang berguna untuk menambah kekuatan dari industri perbankan nasional sesuai dengan Arsitektur Perbankan Indonesia. Maka salah satu upaya adalah dengan meningkatkan kualitas pelaksanaan Good Corporate Governance (GCG).

Untuk itu, diharapkan penerapaan dan pelaksanaan GCG dalam dunia perbankan harus mengikuti prinsip-prinsip dari Good Corporate Governance secara total dan mutlak yang telah ditetapkan dalam Surat Edaran Kepada Semua Bank Umum di Indonesia, perihal Pelaksanaan Good Corporate Governance bagi Bank Umum No. 9/12/DPNP tanggal 30 Mei 2007 yang menetapkan Peraturan Bank Indonesia Nomor 8/4/PBI/2006 tanggal 30 Januari 2006 tentang Pelaksanaan Good Corporate Governance bagi Bank Umum dan Peraturan Bank Indonesia No. 8/14/PBI/2006 mengenai Perubahan atas Peraturan Bank Indonesia Nomor 8/4/PBI/2006 tentang Pelaksanaan Good Corporate Governance bagi Bank Umum.

Seharusnya suatu sistem good corporate governance dapat mengatur kewenangan direksi, yang bertujuan untuk mampu menahan direksi agar tidak menyalahgunakan kewenangan tersebut dan untuk memastikan bahwa direksi bekerja semata-mata untuk kepentingan perusahaan. $G C G$ yang tidak efektif adalah penyebab terjadinya krisis ekonomi dan kegagalan perusahaan-perusahaan di Indonesia, termasuk perusahaan perbankan. Internal audit merupakan katalis yang dapat meningkatkan efektivitas dan efisiensi organisasi, dengan memberikan rekomendasi dan wawasan berdasarkan suatu analisis dan penilaian data dan proses bisnis.

Perusahaan mempekerjakan internal auditnya sendiri untuk melakukan audit keuangan maupun audit operasional. Pelaksanaan internal audit sangat berperan bagi 
manajemen yang telah menerapkan pengendalian internal yang merupakan bagian dari suatu perusahaan itu sendiri. Internal audit yang memiliki lebih banyak pengetahuan mengenai operasional dan pengendalian internal perusahaan ketimbang auditor eksternal, dikarenakan menghabiskan waktunya hanya pada suatu perusahaan. Maka, jenis pengetahuan tersebut dapat menjadi penting bagi tata kelola perusahaan yang baik.

Masalah yang kemudian timbul berkaitan dengan peranan internal audit adalah seberapa besar keberadaan internal audit dalam memberikan nilai tambah (value added) bagi nilai perusahaan itu sendiri. Nilai perusahaan yang baik juga merupakan dampak dari adanya tata kelola perusaahaan yang baik. Sehingga, peranan dari internal audit dalam GCG sangatlah penting.

Oleh karena itu dalam mewujudkan GCG dibutuhkan peran pihak-pihak tertentu, terutama peran internal audit secara langsung. Karena dalam hal ini internal audit berperan dalam mengawasi dan mengevaluasi kegiatan operasional perusahaan dengan memastikan bahwa perusahaan telah melakukan praktik-praktik dalam penerapan prinsip-prinsip Good Corporate Governance (GCG) di dalam perusahaan yang antara lain meliputi : akuntabilitas, pertanggung jawaban, keterbukaan, kewajaran dan kemandirian.

Objek dari penelitian ini adalah PT. Bank Tabungan Negara (Persero), Tbk kantor cabang Manado yang merupakan salah satu BUMN (Badan Usaha Milik Negara) yang bergerak dibidang perbankan dan memiliki kewajiban dalam menerapkan prinsip-prinsip GCG. Penerapan dan pelaksanaan Good Corporate Governance diharapkan dapat membuat nilai BUMN menjadi maksimal, dengan cara meningkatkan prinsip keterbukaan, akuntabilitas, dapat dipercaya, bertanggung jawab, dan adil agar perusahaan memiliki daya saing yang kuat, baik secara nasional maupun internasional. Hal ini sesuai dengan Tujuan Penerapan Good Corporate Governance yang tertuang pada pasal 4 Surat Perintah Mentri BUMN Nomor: PER - 01/MBU/2011.

Pelaksanaan Good Corporate Governance $(G C G)$ pada PT. Bank Tabungan Negara, Tbk Manado mengalami beberapa kendala. Kendala tersebut diantaranya adalah kurangnya pemahaman dan pengetahuan tentang GCG dari karyawan itu sendiri, kurangnya komitmen dalam menerapkan GCG, juga sering terjadi perbedaan pendapat dalam pengambilan keputusan.

\section{TINJAUAN PUSTAKA}

\subsection{Internal Audit}

Menurut Arens dkk. (2011:450) Audit internal dilakukan oleh seseorang yang berasal dari dalam organisasi yang bersangkutan yang disebut dengan auditor internal yang berfungsi untuk membantu perusahaan mencapai tujuannya dengan pendekatan ketat dan sistematis supaya dapat melakukan pengevaluasian dan peningkatkan terhadap manajemen resiko, pengendalian dan proses tata kelola yang efektif

\subsection{Pengertian Good Corporate Governance (GCG)}

Dalam Good Corporate Governance (GCG) tidak ada pengertian tunggal yang dipatenkan menjadi sebuah pengertian atau definisi resmi. Namun pada dasarnya berbagai pengertian mengenai GCG memiliki makna yang sama. Contohnya, Cadbury Report atau Komite Cadbury yang mengeluarkan definisi khusus mengenai GCG yaitu prinsip yang mengearahkan dan mengendalikan perusahaan agar mencapai keseimbangan antara kekuatan serta kewenangan perusahaan dalam memberi pertanggungjawabannya kepada para shareholder khususnya, dan stakeholder pada umumnya (IBI 2017 : 245).

\subsection{Prinsip-Prinsip GCG}

Prinsip-prinsip good corporate governance menurut Menteri BUMN Nomor. KEP117/M-MBU/2002 tentang penerapan praktik GCG pada BUMN pasal 3 yaitu: 
a. Keterbukaan informasi atau Transparansi, merupakan keterbukaan dalam pelaksanaan proses pengambilan keputusan dan keterbukaan untuk mengemukakan informasi materiil dan relevan mengenai perusahaan dan mencegah upaya penyembunyian informasi yang relevan bagi pengguna maupun stakeholder.

b. Akuntabilitas (Accountability) adalah suatu kejelasan fungsi, pertanggungjawaban dan pelaksanaan struktur dan elemen (organ) sehingga pengelolaan perusahaan dapat terlaksana secara efektif.

c. Kemandirian adalah keadaan di mana pengelolaan perusahaan secara profesional tanpa pengaruh atau tekanan dan benturan kepentingan dari pihak manapun, yang tidak sesuai dengan peraturan perundang-undangan yang berlaku dan prinsip-prinsip korporasi sehat.

d. Pertanggungjawaban, merupakan kesesuaian terhdap pengelolaan perusahaan sesuai peraturan perundang-undangan yang berlaku dan prinsip-prinsip korporasi yang sehat.

e. Kewajaran (Fairness) merupakan kesetaraan dan suatu perlakuan yang adil di dalam pemenuhan hak-hak stakeholder yang timbul berdasarkan peraturan perundang-undangan yang berlaku dan perjanjian.

\subsection{Pedoman Pokok Pelaksanaan GCG}

Menurut Komite Nasional Kebijakan Governance (KNKG), pedoman pokok pelaksanaan GCG adalah sebagai berikut :

1. Transparansi (Transparency)

a. Tersedianya informasi perusahaan secara tidak berbelit-belit, memadai, tepat waktu, akurat dan dapat diperbandingkan serta dengan mudah diakses oleh para pemangku kepentingan sesuai dengan haknya.

b. Informasi yang harus diungkapkan harus meliputi namu juga tidak terbatas hanya pada, visi, misi, strategi perusahaan dan sasaran usaha, keadaan finansial, kompensasi dan susunan dari pengurus, pemegang saham pengendali, kepemilikan saham oleh anggota Direksi dan Dewan Komisaris beserta keluarganya di dalam perusahaan dan perusahaan lainnya, sistem manajemen risiko, pengawasan dan internal control, sistem dan pelaksanaan GCG serta tingkat kepatuhannya, dan kejadian penting yang dapat mempengaruhi kondisi suatu perusahaan.

c. Prinsip keterbukaan atau transparansi yang dianut perusahaan tidak mengurangi kewajiban dalam memenuhi ketentuan kerahasiaan perusahaan sesuai dengan peraturan perundang-undangan, rahasia jabatan, dan hak-hak pribadi.

d. Kebijakan perusahaan harus secara tertulis dan proporsional dikomunikasikan kepada para pemangku kepentingan.

2. Akuntabilitas (Accountability)

a. Perusahaan harus menetapkan job description atau suatu rincian tugas dan tanggung jawab masing-masing organ perusahaan dan semua karyawan secara jelas dan selaras dengan visi, misi, nilai-nilai perusahaan (corporate values), dan strategi perusahaan.

b. Mempunyai keyakinan dan kepercayaan yang harus dilakukan perusahaan, pada semua elemen perusahaan dan karyawan mempunyai skill atau kemampuan sesuai dengan tanggung jawab, tugas dan perannya dalam pelaksanaan GCG.

c. Perusahaan harus memastikan adanya sistem pengendalian internal yang efektif dalam pengelolaan perusahaan.

d. Perusahaan harus memiliki tolak ukur kinerja untuk semua organ perusahaan, yang konsisten atau sesuai dengan sasaran usaha perusahaan, juga memiliki sistem penghargaan dan sanksi (reward and punishment system).

e. Perusahaan harus memiliki code of conduct (pedoman perilaku) dan etika bisnis sebagai dasar dari setiap pelaksanaan tugas dan tanggung jawab dari setiap organ perusahaan.

3. Responsibilitas (Responsibility) 
a. By-laws yang memiliki maksud bahwa setiap jajaran perusahaan harus berpegang pada prinsip kehati-hatian dan memastikan kepatuhan pada peraturan perundangundangan, peraturan perusahaan dan anggaran dasarnya.

b. Tanggung jawab sosial yang harus dilaksanakan perusahaan dengan antara lain peduli terhadap masyarakat dan kelestarian lingkungan terutama di sekitar perusahaan dengan membuat perencanaan dan pelaksanaan yang memadai.

d. Independensi (Independency)

a. Setiap organ perusahaan harus berupaya bebas benturan dari kepentingan (conflict of interest), segala pengaruh, tekanan atau dominasi oleh pihak manapun, tidak terpengaruh pada kepentingan khusus sehingga pengambilan keputusan dapat dilakukan secara obyektif.

b. Masing-masing jajaran perusahaan harus melaksanakan kewajiban fungsi dan tugasnya sesuai dengan anggaran dasar dan peraturan perundang-undangan, tidak saling mendominasi dan atau melalikan bahkan melempar tanggung jawab antara satu dengan yang lainnya.

5. Kewajaran dan Kesetaraan (Fairness)

a. Perusahaan memberikan kesempatan pada pemangku kepentingan, sehingga dapat memberikan pendapat dan saran yang berguna bagi kepentingan perusahaan. Selain itu juga dapat dibukanya akses informasi dengan berpengang pada prinsip transparansi dalam lingkup struktur dan kedudukan masing-masing.

b. Perlakuan yang adil, setara dan wajar dari perusahaan pada para pemangku kepentingan sesuai dengan manfaat dan kontribusi yang diberikan pada perusahaan.

c. Pemberian kesempatan yang harus diberikan oleh perusahaan, kesempatan yang sama dalam penerimaan karyawan, berkarir dan melaksanakan tugasnya secara profesional tanpa membedakan suku, ras, golongan, agama, gender, dan kondisi fisik.

\subsection{Hubungan Internal Audit}

Tata kelola merupakan bagian dari definisi internal audit dan termasuk dalam standard serta practice advisory dari IPPF. Ikatan Bankir Indonesia (2017) menyatakan bahwa :

Sesuai Attribute Standard 1220 aktivitas dan peran Satuan Kerja Audit Internal (SKAI) dalam tata kelola adalah melakukan pemeriksaan dan memberi rekomendasi untuk perbaikan tata kelola untuk mencapai tujuan sebagai berikut :

a. Meningkatkan penerapan etika dan nilai-nilai yang disepakati dalam organisasi;

b. Memastikan adanya akuntabilitas dan pengaturan kinerja yang efektif;

c. Mengomunikasikan risiko dan control kepada seluruh bagian dari manajemen yang memerlukannya;

d. Mengoordinasikan aktivitas dan informasi dengan dewan direksi, auditor ekternal dan manajemen.

\section{METODE PENELITIAN}

Penelitian ini adalah penelitian kualitatif deskriptif. Sugiono (2013:13) menyatakan bahwa penelitian deskriptif yaitu penelitian yang bertujuan untuk menyatakan suatu situasi secara sistematis dalam bidang tertentu yang menjadi pusat pemikiran si peneliti secara fakta. Penelitian ini dilaksanakan di kota Manado, dengan objek penelitian yaitu di PT. Bank Tabungan Negara (Persero), Tbk kantor cabang Manado yang terletak di Jl. Wolter Mongisidi No.56, Bahu, Malalayang, Manado, Sulawesi Utara. Dengan waktu penelitian dimulai sejak bulan Desember 2017 sampai selesai

Metode analis yang digunakan dalam penelitian ini adalah metode analisis deskriptif, yaitu metode dengan cara mengumpulkan, mengklasifikasikan, menganalisis, dan menginterpretasikan data-data yang diperoleh dari perusahaan sehingga dapat memberikan 
suatu gambaran mengenai keadaan yang sebenarnya. Selanjutnya, permasalahan dan hasil penelitian diuraikan dan dibandingkan dengan aturan-aturan atau pedoman-pedoman, bukubuku untuk dijadikan sebagai acauan dalam pembahasan oleh peneliti terhadap hasil penelitian. Sehingga nantinya dapat beroleh kesimpulan.

\section{HASIL ANALISIS DAN PEMBAHASAN}

4.1. Hasil analisis

\subsubsection{Pelaksanaan Prinsip-Prinsip GCG Pada Bank BTN Manado}

Pelaksanaan good corporate governance bank berada dalam tahap meningkatkan penerapan tata kelola bank dengan perkembangan regulasi terkait diantaranya adalah Peraturan Otoritas Jasa Keuangan (OJK) No.55 tahun 2016 tentang Penerapan Tata Kelola Bagi Bank Umum. Bank BTN Manado melaksanakan good corporate governance. Berdasarkan wawancara dengan narasumber (dapat dilihat pada transkrip wawancara IV) bahwa dalam pelaksanaan tata kelola perusahaan, bank menjalankan 5 prinsip utama Good Corporate Governance yang diberikan sebutan TARIF. Prinsip-prinsip GCG tersebut antara lain transparansi, akuntabilitas, responsibilitas, independensi, fairness. Prinsip-prinsip GCG yang diterapkan Bank BTN Manado adalah sebagai berikut :

1. Transparansi (Transparency)

BTN Manado melaksanakan briefing pagi setiap harinya. Pada saat itu maka akan dibahas mengenai sasaran usaha dan strategi dari perusahaan. Pengungkapan visi dan misi Bank BTN Manado telah dimuat di website resmi Bank BTN, karena untuk setiap kantor cabang Bank BTN memiliki visi dan misi yang sama.

Dalam transparansi atas laporan keuangan serta informasi yang terkait dengan kondisi keuangan perusahaan pada publik, Bank BTN Manado tidak menunjukkannya (tidak dipublikasi) karena yang berhak adalah Bank BTN kantor pusat. Bank BTN kantor pusat mempublikasi laporan keuangan perusahaan secara keseluruhan pada website resminya. Sedangkan dalam transparansi keuangan perusahaan kepada karyawan akan diinformasikan pada rapat kinerja awal bulan terkait neraca bank. Segala informasi dari setiap unit yang ada di Bank BTN Manado menjadi konsumsi bersama.

Adanya prinsip transparansi diikuti dengan aturan kewajiban untuk memenuhi kerahasiaan perusahaan telah dilaksanakan oleh perusahaan. Kerahasiaan yang dilaksanakan adalah hanya untuk kerahasiaan data nasabah. Data nasabah tidak dipublikasi secara umum. Tetapi bisa juga dilihat jika bank memerlukannya.

2. Akuntabilitas (Accountability)

Bank BTN Manado mempertanggungjawabkan kinerja secara transparan untuk kepentingan bank dengan tetap memperhitungkan kepentingan pemegang saham dan pemangku kepentingan lain. Namun untuk rincian tugas dan tanggung jawab masing-masing organ dalam kantor cabang, terkait tugas pokok fungsi dari setiap unit karena yang berwenang untuk melakukannya dari kantor pusat. Bank BTN kantor cabang Manado hanya menjalankan dan mempertanggungjawabkan tugas dan tanggung jawab yang diberikan.

Dalam mendukung dan melaksanakan prinsip akuntabilitas atas kompetensi dan kemampuan semua organ perusahaan sesuai tugas dan tanggung jawab, Bank BTN Manado melakukan penempatan karyawan melalui 2 cara yaitu :

a. Perekrutan awal. Jika dari awal karyawan tersebut contohnya ditempatkan di accounting unit. Selanjutnya untuk mendukung akuntabilitas atas kompetensi dan kemampuan semua organ perusahaan, bank melakukan 2 cara analisa yaitu penilaian hard kompetensi dan soft kompetensi. Hard kompetensi untuk menganalisa bagaimana karyawan bekerja, target tercapai atau tidak. Sedangkan, soft kompetensi adalah menganalisa karyawan dari kepribadiannya, contohnya jika berkepribadiam pendiam ditempatkan dibagian analis. 
b. Kebutuhan operasional. Bank akan melihat bagian operasional yang membutuhkan karyawan.

Setelah dilakukan penempatan karyawan, maka akan diberikan pengetahuan mengenai posisi pekerjaannya, tugas dan tanggung jawabnya. Namun, Bank BTN memiliki prinsip bahwa semua orang harus mengetahui tanpa melihat bidang studinya.

Bank BTN Manado juga memiliki komitmen bahwa dalam perihal akuntabilitas dalam tugas dan tanggung jawab karyawan akan selalu dinilai dan dikontrol. Jika ada karyawan malas maka perusahaan akan memberikan motivasi lewat konseling. Kewajaran dalam penempatan tugas karyawan 3 bulan maksimal 3 tahun penempatan. Maksimal untuk penempatan pegawai 1 unit selama 3 tahun. Selain itu Bank BTN Manado akan mengadakan rapat KPC (Komite Personalia Cabang) untuk individu yang berkompeten tetapi tidak mau penempatan awalnya.

Dalam pembuatan rincian tugas dan tanggung jawab semua organ perusahaan, baik Bank BTN kantor cabang Manado sama seperti Bank BTN Pusat yang mengacui pada pedoman perilaku atau code of conduct yang telah disepakati. Selain itu terdapat aturan SMK (Sistem Manajemen Kinerja) sebagai aturan dalam kerja dari awal diterima dan ditempatkan. Bank juga melakukan penilaian etika kepada karyawannya melalui PSKT (Panduan Sasaran Kinerja Tahunan).

\section{Pertanggungjawaban (Resposibility)}

Selain aturan dari perusahaan sendiri, Bank BTN Manado melaksanakan aturan yang berlaku umum seperti peraturan dari Bank Indonesia, Keputusan Menteri BUMN. Bank BTN Manado mematuhi peraturan dan ketentuan perundang-undangan yang berlaku dan melaksanakannya dalam tata kelola perusahaan. Perseroan telah membentuk unit yang secara khusus menangani kegiatan CSR, yaitu Unit Community Development Program yang berada di bawah Corporate Secretary Division. Bank BTN Manado memperhatikan nilai-nilai sosial dalam bentuk tanggung jawab kepada masyarakat atau publik.

Selain pertanggungjawaban kepada publik juga bertanggungjawab kepada karyawannya. Hal ini dilihat dari adanya aturan perusahaan yaitu aturan SMK(Sistem Manajemen Kinerja) untuk mengevaluasi, menilai individu dalam pelaksanaan tugas dan tanggungjawab. Bank BTN Manado memiliki acuan aturan perusahaan dalam menjalankan operasionalnya yaitu KD (Ketetapan Direksi), PD (Peraturan Direksi), SE (Surat Edaran) dan Memo. Dalam pertanggungjawaban bank terhadap karyawan terdapat Manajemen Resiko seperti ada perjalan dinas atau peninjauan lokasi perumahan, bank akan memberikan asuransi jika terjadi sesuatu hal. Hal ini adalah bentuk dari tanggung jawab terhadap ketenagakerjaan, keselamatan dan kesehatan kerja karyawan. Bank BTN Manado juga menunjukkan pertanggungjawaban terkait operasioan peklayanan yaitu dengan melihat adanya mitigasimitigasi resiko. Contohnya, orang mengambil kredit Rp100.000.000,- dengan angsuran Rp2.000.000,-/bulan. Sedangkan gaji orang tersebut hanya Rp3.000.000 maka bank tidak akan memberikan kredit tersebut karena sudah melebihi potongan setengah gajinya, dengan memperhitungkan kelangsungan hidup ekonomi orang yang mengajukan kredit tersebut.

Bank BTN Manado menunjukkan pertanggungjawaban kepada publik namun harus seijin kantor pusat. Bank BTN Manado pernah melakukan CSR seperti adanya program pengembangan sosial dan kemasyarakatan dalam bidang agama. Kegiatan dari program tersebut adalah dengan memberi bantuan kepada gereja, mesjid. Bank BTN Manado pernah mendapatkan penghargaan sebagai kantor cabang dengan layanan terbaik di kantor wilyah 5, branch manager terbaik oleh DPD REI (Dewan Perwakilan Daerah Real Estate Indonesia).

4. Independency (Kemandirian)

Bank BTN memiliki Pedoman Penanganan Benturan Kepentingan yang disahkan melalui Peraturan Direksi No. 31/PD/CSD/2010 tanggal 22 Desember 2010, selain itu juga memiliki anggaran dasar. Kedua hal tersebut menjadi landasan bagi Bank BTN Manado 
dalam mengelola secara professional tanpa benturan pihak manapun. Baik atasan maupun bawahan akan selalu dinilai proses kerja, kinerja dan etikanya melalui PSKT (Penilaian Sasaran Kinerja Tahunan), selalu mengkomunikasikan terkait kondisi perusahaan dengan seluruh karyawan, sehingga baik bawahan dan atasan saling mengetahui. Selalu diperiksa secara berkala oleh akuntan publik, juga OJK. Sehingga jika terjadi kecurangan akan ditindak lanjuti.

5. Kewajaran (Fairness)

Pada Bank BTN Manado kesetaraan kepada semua organ perusahaan dalam menyampaikan pendapat dilakukan dengan melaksanakan brifieng baik per unit dilaksanakan setiap pagi atau seluruh karyawan kantor cabang Manado pada Senin pagi. Setiap karyawan dapat menyampaikan saran, pendapat atau usul mengenai pekerjaannya untuk kemajuan perusahaan. Baik komunikasi antara atasan dan bawahan dilakukan dengan cara konseling face to face dan komunikasi untuk sesama manajemen dengan melakuka sharing yaitu pada rapat KPC (Komite Personalia Cabang).

Bank BTN Manado melaksanakan prinsip kewajaran pada laporan kondisi perusahaan. Hasil laporan kondisi Bank BTN Manado atau terkait keuangan, akan diterima oleh Bank BTN Kantor Pusat kemudian akan digabungkan secara keseluruhan dan dipublikasikan. Bank BTN juga memiliki ketentuan Anggaran Dasar dan itu berlaku juga untuk setiap kantor cabang Bank BTN termasuk Bank BTN KC Manado.

Kewajaran dan kesetaraan dalam penerimaan karyawan pada Bank BTN Manado dilakukan tanpa membedakan ras, suku, agama, golongan dan gender. Namun, disi lain Bank BTN Manado memperhatikan kondisi fisik khususnya bagi yang akan ditempatkan di bagian frontliner seperti teller, CS. Selain itu bank telah menetapkan remunerasi dengan berpedoman pada Piagam Komite Remunerasi dan Nominasi, memberikan pelatihan bagi karyawan, memberikan peluangan dan menetapkan kenaikan grade (dalam hal ini terkait jenjang karir), besarnya gaji dan penentuan dan penilai kerja lainnya yang dilakukan secara obyektif.

\subsubsection{Ruang Lingkup Internal Audit Bank BTN}

Berdasarkan wawancara dengan narasumber (dapat dilihat pada transkrip wawancara II) yang mengatakan bahwa pekerjaan audit oleh IAD pada BTN mencakup seluruh aspek dan unsur kegiatan organisasi bank. Sesuai data pada Laporan Tahunan BTN 2017 mengenai internal audit, bahwa pekerjaan audit tersebut dilakukan melalui pendekatan riskbased audit dengan melihat minimal 8 risiko yang mengacu pada Peraturan Bank Indonesia, yaitu: Risiko Kredit, Risiko Pasar, Risiko Likuiditas, Risiko Operasional, Risiko Hukum, Risiko Reputasi, Risiko Strategis, Risiko Kepatuhan. Selain itu ruang lingkup pekerjaan audit oleh DAI/IAD juga mencakup kegiatan badan-badan usaha afiliasi dan anak perusahaan yang secara langsung ataupun tidak langsung diperkirakan dapat mempengaruhi terselenggaranya secara baik kepentingan Bank.

Ruang lingkup pekerjaan Internal Audit Division (IAD) meliputi pemeriksaan (audit) dan penilaian atas efektivitas dari manajemen resiko (risk management), efektivitas \& kecukupan dari sistem pengendalian intern, kualitas kinerja dalam melaksanakan tanggung jawab yang telah digariskan, serta efektivitas governance processes dengan melakukan :

1. Audit ketaatan (compliance audit),

2. Audit keuangan (financial audit),

3. Audit operasional (operational/ management audit),

4. Audit rating,

5. Audit TSI (information and technology system audit),

6. Audit khusus dan investigasi (special dan investigation audit),

7. Pemantauan secara off-site atau monitoring (desk audit),

8. Penilaian atas sistem pengamanan harta kekayaan Bank termasuk sumber daya dan dana, memastikan eksistensi harta kekayaan Bank. 


\subsubsection{Tugas dan Tanggung Jawab Internal Audit Bank BTN}

Berdasarkan dokumentasi dan observasi ditemukan data yang dimaut dalam Annual Report BTN 2017 yang menyatakan sesuai dalam Piagam Audit BTN bahwa fungsi dan tugas Internal Audit Division adalah membantu tugas Direktur Utama dan Dewan Komisaris serta seluruh tingkatan manajemen dalam memastikan kecukupan sistem pengendalian intern bank dan memberikan saran-saran yang strategis dan konstruktif terhadap pengelolaan bank dalam kerangka penerapan tata kelola bank yang baik dan sehat dengan tugas-tugas sebagai berikut :

1. Merumuskan perencanaan dan menjabarkan secara operasional pelaksanaan audit, serta pemantauan tindak lanjut atas hasil audit

2. Membuat analis dan penilaian di bidang keuangan, akuntansi, operasional dan kegiatan lainnya melalui audit secara on-site dan pemantauan secara off-site, termasuk melakukan audit menajemen terhadap seluruh unit kerja perseroan.

3. Memberikan saran perbaikan dan informasi yang obyektif tentang kegiatan yang diaudit kepada semua tingkatan manajemen.

4. Melakukan pemeriksaan, penilaian dan mengidentifikasi segala kemungkinan untuk meningkatkan efisiensi dan efektifitas di bidang keuangan, akuntansi, operasional, pengggunaan sumber daya, pemasaran, teknologi informasi dan kegiatan lainnya yang terkait dengan operasional dan bisnis bank berlandaskan pada semua ketentuan yang berlaku.

5. Melakukan pengujian dan evaluasi guna meningkatkan/ menyempurnakan efektivitas manajemen risiko, pengendalian intern dan proses pengelolaan (governance processes).

\subsection{Pembahasan}

\subsubsection{Analisis Pelaksanaan Prinsip-Prinsip GCG Pada Bank BTN Manado}

Bank Tabungan Negara Manado telah menerapkan dan melaksanakan good corporate governance dengan menggunakan prinsip-prinsip tersebut dan disebut dengan nama prinsip TARIF. Berdasarkan hasil penelitian, maka peneliti akan membahas dan memberikan analisis terkait pelaksanaan prinsip-prinsip GCG pada Bank BTN Manado. Dengan mengambil patokan sesuai pedoman pokok pelaksanaan Good Corporate Governance (GCG) oleh Komite Nasional Kebijakan Governance (KNKG), yaitu sebagai berikut :

1. Pelaksanaan prinsip transparansi pada Bank BTN Manado

Pada Bank Tabungan Negara kantor cabang Manado, pelaksanaan prinsip transparansi sudah berjalan secara keseluruhan. Hal ini dapat dibuktikan dengan adanya aktivitas atau kegiatan yang dilakukan oleh bank, diantaranya adalah sebagai berikut :

a. Transparansi atas informasi mengenai visi, misi, sasaran usaha dan strategi perusahaan.

Bank BTN Manado telah transparan. Hal ini dibuktikan dengan visi, misi yang telah dimuat di website resmi bank. Selain itu, sasaran usaha dan strategi dari bank diketahui oleh seluruh karyawan Bank BTN. Terkait sasaran dan strategi kantor cabang Manado sama seperti sasaran dan strategi Bank BTN Pusat dan dipublikasi juga kepada masyarakat.

b. Transparansi atas laporan keuangan serta informasi yang terkait dengan kondisi keuangan perusahaan.

Pada Bank BTN Manado transparansi mengenai laporan keuangan serta informasi yang terkait dengan dengan kondisi keuangan perusahaan sudah cukup transparan. Hal ini dibuktikan dengan adanya rapat kinerja pada awal bulan dan akan membahas mengenai neraca bank. Pelaporan terkait neraca bank akan disampaikan oleh accounting and control unit. Selain itu dibuktikan dengan adanya briefing atau pada Bank Tabungan Negara Manado disebut dengan KBK Pagi, dimana semua karyawan berkumpul dan akan bersama membahas kondisi perusahaan dan kondisi keuangannya.

c. Kewajiban untuk memenuhi ketentuan kerahasiaan perusahaan. 
Bank Tabungan Negara kantor cabang Manado dalam menjalankan prinsip transparansi, tidak mengurangi kewajiban dari setiap karyawan dalam hal pemenuhan ketentuan kerahasiaan perusahaan sesuai dengan peraturan undang-undang. Sesuai dengan pokok pedoman transparansi yang telah tertulis pada code of conduct atau pedoman etika bisnis dan etika kerja.

2. Pelaksanaan prinsip akuntabilitas Bank BTN Manado

Dalam pelaksanaannya masih belum berjalan secara keselurahan, meskipun nilai penerapan prinsip akuntabilitas pada perusahaan dapat dikatakan cukup baik. Hal ini dikarenakan masih ditemukan kurangnya komitmen dan konsistensi dari karyawan dalam melaksanakan tugas dan tanggung jawabnya. Dibuktikan dengan observasi dari peneliti bahwa adanya hasil yang belum maksimal dari karyawan, yang terdapat pada penilaian standar kinerja tahunan (PSKT). Selain itu juga dibenarkan oleh narasumber yang telah diwawancara (dapat dilihat di transkrip wawancara IV)

a. Akuntabilitas atas rincian tugas dan tanggung jawab masing-masing organ perusahaan.

Pelaksanaan pedoman pokok prinsip akuntabilitas atas rincian tugas dan tanggung jawab masing-masing organ perusahaan pada Bank BTN Manado telah diterapkan dan terlaksana dengan baik. Hal ini ditandai dengan adanya jobdescription atas rincian tugas dan tanggung jawab masing-masing organ perusahaan.

b. Akuntabilitas atas kompetensi dan kemampuan semua organ perusahaan sesuai dengan tugas dan tanggung jawab.

Bank BTN Manado telah melaksankan prinsip ini dengan baik. Masing-masing pihak yang menduduki jabatan dalam organ perusahaan dan manajemen wajib memiliki kompetensi yang sesuai dan melaksanakan tanggung jawabanya dan memahami perannya dalam pelaksanaan tata kelelola perusahaan yang baik. Dibuktikan juga karena adanya aturan dan penilaian dari pihak bank sendiri terhadap karyawan yang berkompeten dan sanksi bagi karyawan jika tidak menjalankan sesuai tugas dan tanggung jawabnya.

c. Kesesuaian antara tugas dan tanggung jawab semua organ perusahaan dengan pedoman perilaku (code of conduct) yang telah disepakati.

Bank BTN telelah menerapkan Pedoman Etika Bisnis dan Perilaku (Code of Conduct) yang disahkan melalui Peraturan Direksi No. 16/PD/CMPD/2015. Dalam pembuatan job description atau rincian tugas dan tanggung jawab setiap organ, Bank BTN mengacu pada pedoman perilaku atau code of conduct yang telah disepakati. Hal ini berarti bahwa tugas dan tanggung jawab semua organ perusahaan dengan code of conduct telah sesuai.

3. Pelaksanaan prinsip responsibilitas Bank BTN Manado

Pada Bank Tabungan Negara Manado, pelaksanaan prinsip pertanggungjawaban sudah berjalan secara keseluruhan. Nilai dari penerapan prinsip pertanggungjawaban pada perusahaan juga cukup baik. Hal tersebut dibuktikan dengan adanya beberapa kegiatan berikut :

a. Kepatuhan semua organ perusahaan terhadap peraturan perundang-undangan serta peratuan perusahaan.

Bank Tabungan Negara Manado dalam menjalankan aktivitas operasional bank telah mematuhi peraturan perundang-undangan dan peraturan perusahaan yang berlaku. Hal ini dibuktikan dengan adanya Sistem Pengendalian Internal (SPI), pelaksanaan program Whistleblowing System (WBS) dan adanya sistem monitoring kepatuhan (Compliance Control Application) oleh petugas BCSO dalam melakukan proses evaluasi di kantor cabang Manado. Bahkan Bank Tabungan Negara Manado dalam menunjukkan pertanggungjawabannya pada proses pelayanan bank, memperoleh penghargaan sebagai kantor cabang dengan layanan terbaik di kantor wilayah 5.

b. Pelaksanaan tanggung jawab sosial terhadap masyarakat serta lingkungan di sekitar perusahaan (CSR). 
Bank Tabungan Negara kantor cabang Manado telah melaksanakan tanggung jawab sosialnya terhadap masyarakat dan lingkungan dengan baik. Bank BTN Manado memiliki komitmen yang kuat untuk turut serta meningkatkan kesejahteraan masyarakat disekitar perusahaan, baik di bidang agama, ekonomi, sosial, pendidikan maupun kesempatan kerja. Hal ini ditunjukkan dengan bantuan untuk gereja, mesjid dan adanya kebijakan dalam penerimaan anak-anak PKL bagi siswa maupun magang sebagai bentuk kepedulian bagi pendidikan.

4. Pelaksanaan prinsip independensi Bank BTN Manado

Pada Bank BTN Manado, penerapan dan pelaksanaan prinsip independensi sudah berjalan secara keseluruhan. Berikut adalah beberapa kegiatan yang dilakukan oleh bank:

a. Obyektifitas dalam pengambilan keputusan tanpa dominasi serta benturan kepentingan pihak manapun.

Independensi dan obyektifitas dari suatu perusahaan sangatlah penting dan harus diutamakan dalam pelaksanaanya, sehingga dapat tercipta suatu korporasi yang sehat. Bank BTN Manado telah dikelola secara profesional, dengan menghindari berbagai benturan kepentingan maupun dominasi, serta tekanan atau pengaruh dari pihak manapun tanpa membedakan yang tidak sesuai dengan peraturan perundang-undangan yang berlaku serta prinsip korporasi yang sehat.

b. Kewajiban dalam melaksanakan fungsi dan tugas sesuai dengan anggaran dasar, peraturan perundang-undangan yang berlaku serta menghormati hak, kewajiban dan tanggung jawab masing-masing.

Hal ini telah diterapkan dan secara keseluruhan dilaksanakan oleh Bank Tabungan Negara (BBTN) Manado dengan konsisten. Bank BTN Manado mewajibkan semua organ bank melaksanakan fungsi dan tugasnya sesuai dengan anggaran dasar serta peraturan perundang-undangan yang berlaku. Komitmen dari bank ditunjukkan juga dengan adanya penilaian etika, kinerja karyawan dan adanya sanksi bagi yang tidak mematuhinya.

5. Pelaksanaan prinsip fairness Bank BTN Manado

Prinsip fairness atau kewajaran pada Bank Tabungan Negara Manado hampir dilaksanakan secara keseluruhan. Berikut ini adalah pelaksanaan bank dalam memenuhi prinsip kewajaran :

a. Kesetaraan kepada semua organ perusahaan dalam menyampaikan pendapat untuk kepentingan perusahaan.

Bank Tabungan Negara Manado telah menerapkan dan melaksanakan kesetaraan kepada semua organ perusahaan dalam menyampaikan pendapat untuk kepentingan bank. Dibuktikan dengan adanya komuniksi dua arah yang bebas, terbuka dan bertanggung jawab. Selain itu adanya kegiatan briefing setiap hari dan rapat KPC. Komunikasi baik antara sesama karyawan, atasan dengan bawahan, sesama manajemen. Adanya komunikasi untuk menyampaikan saran, pendapat untuk kemajauan bank sangatlah baik untuk diterapkan dan dilaksanakan. Hal tersebut dapat membantu perusahaan untuk mencapai tata kelola perusahaan yang baik.

b. Kewajaran dan kesetaraan atas perlakuan perusahaan kepada semua organ perusahaan.

Kewajaran dan kesetaraan atas perlakuan perusahaan kepada semua organ perusahaan sangatlah penting untuk dilaksanakan. Hal ini juga menjadi salah satu penilaian dari pelaksanaan prinsip tata kelola perusahaan yang baik. Bank Tabungan Negara Manado telah melaksanakan kewajaran dan kesetaraan kepada semua organ perusahaan dengan baik. Bank BTN Manado memberikan perlakuan yang setara dan wajar (equal treatment) kepada para stakeholders untuk memenuhi hak-hak stakeholders berdasarkan perjanjian dan peraturan perundang-undangan yang berlaku.

c. Kewajaran dan kesetaraan atau perlakuan yang adil dalam hal penerimaan karyawan tanpa membedakan suku, ras, agama, gender, golongan, dan kondisi fisik. 
Hal ini telah dilaksanakan Bank BTN Manado dengan cukup baik, karena dibuktikan dari adanya berbagai karyawan bank dengan suku, agama, ras, golongan, gender dan kondisi fisik. Selain kewajaran dan kesetaraan dalam penerimaan karyawan, bank menunjukkan keadilan pada karyawannya dengan memberikan pelatihan, kebebasan karyawan dalam meniti karirnya, besarnya gaji, penilaian etika dan kinerja karyawn secara obyektif.

Berdasarkan uraian tersebut, maka Good Corporate Governance (GCG) pada Bank Tabungan Negara Manado telah diterapkan secara jelas dan sesuai dengan ketentuan aturan yang berlaku umum, juga sudah sesuai dengan kebijakan dari perusahaan sendiri. Bank Tabungan Negara Manado sudah menerapkan dan secara umum melaksanakan tata kelola perusahaan dengan baik. Hal ini tercermin dari pemenuhan yang memadai atas prinsipprinsip GCG sesuai dengan yang dicantumkan dalam Bab II Tinjauan Pustaka yaitu sesuai dengan aturan Menteri BUMN No. KEP-117/M-MBU/2002. Selain itu telah sesuai dengan pedoman GCG yang dikeluarkan oleh KNKG 2006. Namun, masih terdapat kelemahan dalam pelaksanaan prinsip GCG seperti prinsip akuntabilitas. Walaupun sudah ada aturan dan rincian yang jelas mengenai tugas dan tanggung jawab, namun masih terdapat kurangnya komitmen dalam pelaksanaan tugas dan tanggung jawab dari karyawan yang ada, serta adanya hasil Penilaian Standar Kinerja Tahunan (PSKT) dari individu karyawan tidak mencapai hasil yang maksimal.

\subsubsection{Analisis Peranan Internal Audit Dalam Mewujudkan Pelaksanaan GCG}

Fungsi internal audit merupakan suatu komponen yang penting dalam sistem pengendalian internal perseroan. Fungsi internal audit pada Bank BTN berperan memberikan assurance secara independen dan obyektif serta masukan kepada dewan komisaris dan direksi. Selain itu disebutkan bahwa fungsi internal audit Bank BTN merupakan partner dalam mewujudkan implementasi GCG di lingkungan perseroan agar mampu memberikan nilai tambah bagi perseroan.

Dengan mengambil uraian berdasarkan Effendi (2016:99) peran internal audit dalam mewujudkan Good Corporate Governance (GCG) sebagai tolak ukur, maka peneliti akan membahas aktivitas peran internal audit pada Bank Tabungan Negara dalam mewujudkan pelaksanaan Good Corporate Governance (GCG) sebagai berikut :

1. Mendorong transparansi (transparency) dan integritas (integrity) dalam pelaporan keuangan (financial reporting) perusahaan.

Melalui wawancara, observasi dan tinjauan pustaka yaitu dengan membaca laporanlaporan terkait pada Bank Tabungan Negara, bahwa peran internal audit pada Bank BTN telah terlaksana dengan baik. Hal ini dibuktikan dengan adanya pendampingan dari internal audit ataupun juga internal control kepada auditor eksternal atau counterpart telah transparan dalam memberikan dokumen-dokumen serta data-data yang diperlukan auditor eksternal.

2. Mendorong akuntabilitas (accountability) dalam pengelolaan aset perusahaan.

Berdasarkan wawancara dengan narasumber (dapat dilihat pada transkrip wawancara I) Internal audit Bank BTN telah berperan dalam mewujudkan pelaksanaan prinsip akuntabilitas. Pelaksanaan tersebut adalah dengan adanya tugas dari internal audit yang disebut dengan Audit ICT (Information and Technology System), juga tugas audit untuk melakukan penilaian atas sistem pengamanan harta kekayaan bank termasuk sumber daya dan dana serta memastikan eksisternsi harta kekayaan bank. Dengan melakukan pengelolaan aset secara akuntabel dan bijaksana maka bank dapat mempertanggungjawabkan kepada semua stakeholders.

3. Mendorong pertanggungjawaban (responsibility) perusahaan kepada publik melalui

Corporate Social Responsibility (CSR), Community Development, atau Program Kemitraan dan Bina Lingkungan (PKBL). 
Peranan internal audit pada Bank Tabungan Negara dalam mendukung prinsip resposibilitas adalah hanya berfokus pada pelaksanaan audit ketaatan (compliance). Melakukan pelaksanaan pemeriksaan dan peniliaian ketaatan bank pada aturan, seperti pada aturan undang-undang nomor 32 tahun 2009 tentang perlindungan dan pengelolaan lingkungan hidup, juga pada kebijakan CSR Perseroan Peraturan Direksi Nomor: 29/PD/DSP/2008 tentang Corporate Sosial Responsibility PT Bank Tabungan Negara (Persero) Tbk.

Pada Bank BTN kantor cabang Manado sendiri yang tidak memiliki auditor internal tetapi memiliki accounting and control unit, yang termasuk dalam satuan sistem pengendalian internal bank juga memiliki hubungan dengan internal audit telah berperan dalam mendorong prinsip pertanggungjawaban bank. Hal ini dibuktikan dengan adanya pelaksanaan tugas dalam pemeriksaan laporan keuangan dan kondisi bank, melakukan pengendalian internal yang berguna menghasilkan laporan yang berintegritas dan obyektif. Sehingga laporan tersebut dapat disampaikan ke Bank BTN Pusat dan kemudian dipublikasikan secara keseluruhan terkait laporan tata kelola perusahaan. Terkait peranan dalam mendorong pertanggungjawaban kepada publik melalui CSR (Corporate Social Resposibility) belum berjalan sepenuhnya. Karena hanya mengikuti arahan dari kantor pusat, juga mengingat pelaksanaan CSR Bank BTN kantor cabang Manado harus seijin dan arahan dari Bank BTN Pusat. Namun, internal audit yang dalam kantor cabang oleh accounting and control unit sendiri berperan untuk memeriksa apakah semua proses untuk CSR telah sesuai aturan, seperti jika ada sumbangan karena terkait uang maka akan diperiksa. (Dapat dilihat pada transkrip wawancara I).

4. Mendorong independensi (independency) perusahaan terhadap pihak-pihak terkait, termasuk pemegang saham minoritas.

Peran internal audit atau SPI (Sistem Pengendalian Internal) Bank BTN kantor cabang Manado pada prinsip independensi berdasarkan hasil observasi diperoleh data-data berupa dokumen struktur organisasi dan peneliti telah mengamati secara langsung proses kerjanya. Maka dari itu dapat dikatakan pada prinsip independensi, SPI pada BTN sudah cukup baik. Hal ini dapat dibuktikan dengan adanya kedudukan posisi yang terpisah dari divisi-divisi lain sehingga mempunyai wewenang yang jelas dalam pelaksanaan tugasnya. Posisi internal audit langsung dibawah presiden direktur, jadi tidak ada campur tangan dari unit lain. Selain itu juga adanya peran dari sistem pengendalian internal (SPI).

Pada Bank BTN kantor cabang Manado yang meiliki internal control, memiliki tugas untuk melakukan pemeriksaan job masing-masing unit. Jika dalam melakukan pemeriksaan tersebut, ditemukan masalah maka akan diberikan mulai dari sanksi ringan sampai sanksi berat sesuai dengan kesalahan. Internal Control Bank BTN kantor cabang Manado bertanggung jawab kepada Kacab Audit (Kepala Cabang Audit) selanjutnya diteruskan kepada IAD dan terakhir kepada direktur utama. Selain itu, adanya BCSO (Branch Compliance Suppervisory Officer) yang bertugas mengawasi setiap pegawai dalam kepatuhannya terhadap SOP dan langsung berhubungan dengan Bank Tabungan Negara kantor pusat. BCSO pada Bank BTN Manado sering disebut dengan "orang kantor pusat", hal ini disebabkan dengan independensi dan obyektifitasnya. BCSO inilah yang juga akan berhubungan dengan internal control dan akan melaporkan segala aktivitasnya kepada internal audit.

Walaupun tidak ada internal audit pada Bank BTN Manado tetapi internal audit tetap akan melakukan tugas dan tanggung jawabnya di kantor cabang secara berkala. Seperti adanya audit IT pada Bank BTN Manado, dilakukan sekali dalam setahun atau bisa sampai dua kali dalam setahun. Jenis-jenis audit yang dilakukan pada Bank Tabungan Negara Manado adalah seperti general audit, audit tematik dan audit khusus. 
5. Mendorong kewajaran (fairness) dalam pengadaan barang dan jasa termasuk dipastikannya tidak ada pelanggaran terhadap UU antimonopoli dan persaingan usaha yang sehat.

Peranan internal audit atau SPI Bank Tabungan Negara pada prinsip kewajaran sudah cukup baik. Hal ini dapat dibuktikan dengan hasil wawancara dengan narasumber ke dua (dapat dilihat pada transkrip wawancara II) observasi ditemukan data-data pada ruang lingkup dari internal audit yaitu internal audit ataupun SPI pada kantor cabang memastikan kebijakan pengadaan barang dan jasa perseroan telah dijalankan sesuai dengan ketentuan aturan perundang-undangan serta sistem prosedur dari bank dimana tidak terjadi. Audit dilakukan secara berkala maupun sewaktu-waktu.

\section{KESIMPULAN DAN SARAN}

\subsection{Kesimpulan}

1. Pelaksanaan GCG pada Bank BTN Manado

a. Bank BTN telah menetapkan kebijakan mengenai corporate governance yang harus dipatuhi oleh seluruh organ bank. Dibuktikan dengan adanya dokumen Pedoman Perilaku BTN.

b. Pelaksanaan good corporate governance bank berada dalam tahap meningkatkan penerapan tata kelola bank dengan perkembangan regulasi terkait diantaranya adalah Peraturan Otoritas Jasa Keuangan (OJK) No.55 tahun 2016

c. Secara keseluruhan Bank BTN Manado telah menerapkan dan melaksanakan sesuai 5 prinsip GCG yaitu, transparansi, akuntabilitas, pertanggungjawaban, independensi, dan kewajaran.

d. Namun masih ditemukan kelemahan dalam pelaksanaan prinsip GCG. Dikarenakan adanya kurang komitmen dari karyawan dalam menjalankan tugas dan tanggung jawabnya untuk mencapai sasaran dan tujuan bank.

e. Pelaksanaan GCG pada Bank Tabungan Negara Manado secara keseluruhan telah sesuai dengan pedoman dari Komite Nasional Kebijakan Governance (KNKG)

2. Peranan internal audit dalam mewujudkan pelaksanaan GCG

a. Ruang lingkup internal audit yang telah ditetapkan yaitu didalamnya termasuk melakukan pemeriksaan dan penilaian efektivitas governance processes.

b. Internal audit menilai keandalan dan integritas informasi melalui cara melihat atau melakukan survey dan observasi secara langsung kondisi lingkungan perusahaan.

c. Internal audit menilai kepatuhan terhadap kebijakan prosedur dan peraturan dengan melakukan audit compliance dn penilaian kinerja.

d. Independensi internal audit dapat dilihat dengan jelas dari struktur dan kedudukan organisasinya.

e. Internal audit Bank Tabungan Negara telah berperan dalam mewujudkan pelaksanaan good corporate governance, hal ini dapat dilihat dari :

1) Internal audit mendorong transparansi (transparency) dan integritas (integrity) dalam pelaporan keuangan (financial reporting) perusahaan, seperti dengan adanya pendampingan kepada audit eksternal.

2) Mendorong akuntabilitas (accountability) dalam pengelolaan aset perusahaan. Dengan adanya audit ICT (Information and Technology System).

3) Mendorong pertanggungjawaban (responsibility) perusahaan kepada public melalui Corporate Social Responsibility (CSR), Community Development, atau Program Kemitraan dan Bina Lingkungan (PKBL). Dengan adanya pelaksanaan pemeriksaan dan peniliaian ketaatan bank pada aturan, seperti pada aturan undang-undang nomor 32 tahun 2009 tentang perlindungan dan pengelolaan lingkungan hidup. 
4) Mendorong independensi (independency) perusahaan terhadap pihak-pihak terkait, termasuk pemegang saham minoritas. Kedudukan organisasi yang terpisah dari unit-unit kerja lainnya dan melakukan penilaian secara obyektif, secara terbuka menyampaika kondisi perusahaan dan resiko-resiko yang akan dialami perusahan.

5) Mendorong kewajaran (fairness) dalam pengadaan barang dan jasa termasuk dipastikannya tidakada pelanggaran terhadap UU antimonopoli dan persaingan usaha yang sehat. Adanya audit dan melakukan penilaian terhadap

\subsection{Saran} pengadaan barang menurut kebijakn dan prosedur yang berlaku

Internal audit pada Bank Tabungan Negara secara keseluruhan telah berperan dalam mewujudkan pelaksanaan GCG sehingga bank hanya perlu untuk mempertahankannya dan lebih baik jika terus dapat meningkatkan kualitas dari internal audit. Meningkatkan kualitas dapat dilakukan dengan lebih memiliki para staff yang memiliki kompetensi yang tinggi dan wawasan yang luas, sehingga tujuan pelaksaan audit dapat tercapai. Berikut beberapa hal yang dapat dilakukan internal audit untuk meningkatkan kualitasnya :

1. Dapat meningkatkan ilmu pengetahuan dalam akuntansi melalui pendidikan formal maupun pelatihan-pelatihan atau seminar-seminar. Sehingga dapat menciptakan regulasiregulasi yang baru dari tahun ke tahun.

2. Lebih mensosialisasikan mengenai GCG pada semua organ perusahaan, termasuk pada setiap karyawan yang ada. Memotivasi karyawan sehingga dapat tercipta dan membangun komitmen yang kuat dalam menjalankan tugas dan tanggung jawabnya.

Untuk pelaksanaan GCG pada Bank Tabungan Negara Manado, sebaiknya bank memberikan sanksi yang tegas dan melakukan pemeriksaan secara rutin mengenai kinerja perusahaan. Selain itu lebih membangun hubungan yang baik dalam hal berkomunikasi antara karyawan maupun atasan dan bawahan. Dengan demikian dapat tercipta keselarasan pada karyawan untuk bersama-sama dan secara optimal menjalankan tugas dan tanggung jawabnya. Sehingga dapat mencapai tujuan perusahaan dan meningkatkan nilai perusahaan. Selain itu, dapat melakukan tanggung jawab kepada publik atau CSR lebih sering dan merata keseluruh daerah dengan memberi masukan kepada Bank BTN kantor pusat. Melaksanakan CSR merata keseluruh daerah bukan hanya terpaut atau sering di pulau Jawa. Sehinggaa Bank BTN Manado bisa menambah nilai dari masyarakat di kota Manado.

\section{DAFTAR PUSTAKA}

Agoes, Sukrisno. 2012, Auditing Petunjuk Praktis Pemeriksaan Akuntan Oleh. Akuntan Publik, Jilid 1, Edisi Keempat, Jakarta: Salemba Empat

Anafiah Vidyata, Vera Diyanti, Ratna Wardhani. 2017. The Effect Of Controlling Shareholders And Corporate Governance On Audit Quality. Jurnal Akuntansi dan Keuangan Indonesia Volume 14 Nomor 1, Juni 2017

Arens, Alvin. A, Randal J. Elder, Mark S. Beasley. 2008. "Auditing and Assurance Services." Fifteenth Edition. Pearson Education, Inc. USA. Diterjemahkan oleh Gina Gania dan Tim Perti. 2015. Auditing dan Jasa Assurance. Edisi Kelima belas. Jakarta: Erlangga.

Arens, Alvin. A, Randal J. Elder, Mark S. Beasley. 2011. Audit dan Jasa Assurance: Pendekatan Terpadu (Penerjemah Herman Wibowo). Jakarta: Salemba Empat

Pendekatan Terpadu (Penerjemah Herman Wibowo). 2014. Auditing and Assurance service. Edisi keduabelas. Jilid Satu. Jakarta: Erlangga. Prentice Hall International. New York.

Ashour Mohamad, Eko Sukoharsono, Abdul Gofar. 2015. The Impact Of Competencies, Risk Management And Auditors Interactions On Internal Audit Effectiveness In Libyan 
Commercial Banks. The International Journal of Accounting and Business Society Vol 23 No.1.

Casandra, Febry. 2017. Pengaruh Audit Internal, Pengendalian Internal, dan Komite Audit Terhadap Penerapan Good Corporate Governance Pada BUMN di Kota Surakarta. Naskah Publikasih Februari 2017.

Dewany, Flowurrence. 2015. Analysis Of The Effect Of GCG Quality On The Financial Performance Of Islamic Banks. The Indonesian Accounting Review Vol. 5, No. 2: $119-$ 128.

Djunaedi, Andi. 2013. Peranan Audit Internal Dalam Penerapan Prinsip-Prinsip Good Corporate Governance Pada PDAM Kota Bandung. Jurnal Akuntansi Widyatama.

Effendi, Muh. Arief. 2016. The Porwer of Corporate Governance Teori dan Implementasi. Jakarta: Salemba Empat.

Faisal. 2014. Pengaruh Peranan Audit Internal Terhadap Penerapan Good Corporate Governance Pada PT. Perkebunan Nusantara V (Persero) Pekanbaru. Skripsi. UIN SUSKA Riau. Pekanbaru

Hendro, Tri dan Conny Rahardja. 2014.Bank \& Institusi Keuangan Non Bank Di Indonesia. Yogyakarta: UPP STIM YKPN.

Hery. 2010. Potret Profesi Audit Internal. Bandung :Alfabeta.

Ikatan Bankir Indonesia. 2017. Memahami Audit Intern Bank. Cetakan Kedua. Jakarta: Kompas Gramedia.

Joksimović, Marijana dan Alseddig Ahmed. 2017. The Internal Audit As Function To The Corporate Governance. Economic Review Vol. 14, No 2, 2017: 109-126.

Mauliddyah, Nafisatul. Dwiatmanto dan Maria NP. 2017. Analisis Peran Audit Internal Sebagai Penunjang Penerapan Good Corporate Governance (Studi pada PT. Krakatau Bandar Samudera (KBS) Cilegon-Banten). Jurnal Administrasi Bisnis (JAB)|Vol. 47 No.1 Juni 2017.

Komite Nasional Kebijakan Governance (KNKG). 2006. Pedoman Umum Good Corporate Governance Indonesia. Jakarta.

Komite Nasional Kebijakan Governance (KNKG). 2009. Pedoman Umum Good Corporate Governance (GCG) di Indonesia, 17 Oktober. Jakarta

Menteri Badan Usaha Milik Negara. 2002. Surat Keputusan Nomor: Kep-117/M-Mbu/2002 tentang Penerapan Praktek Good Corporate Governance pada Badan Usaha Milik Negara (BUMN).

Menteri Badan Usaha Milik Negara. 2011. Surat Perintah Menteri BUMN Nomor: PER01/MBU/2011 Tujuan Penerapan Good Corporate Governance

Miranty, Herly dan Sisnuhadi.2011. Corporate Governance and Firm Performance in Indonesia. International Journal of Governance Vol.1, No.2.

Mulyadi. 2014. Auditing Buku 1. Jakarta: Salemba Empat.

Retno Tri. 2012. Peranan Audit Internal dalam Penerapan Good Corporate Governance pada PT. Bank Negara Indonesia (Persero), Tbk Cabang Makassar. Jurnal Akuntansi UP-ACC 254

Richard, Chinn. 2000, Corporate Governance Handbook, Gee Publishing Ltd. London

Puspa, Dianita. 2014. Peran Auditor Internal Dalam Penerapan Good Corporate Governane Studi Pada PT. Jasa Raharja. Jurnal Akuntansi UGM.

Sugiyono. 2013. Metode Penelitian Kuantitatif, Kualitatif dan R\&D. Bandung: Alfabeta http://www.academia.edu/6804279/1_Good_Corporate_Governance

http://auditorinternal.com/2010/01/19/kode-etik-auditor-internal/

www.wikipedia.com

https://www.btn.co.id 